Zabytkoznawstwo i Konserwatorstwo XLIII, Torun 2012

Halina Rosa, Alicja Strzelczyk, Elżbieta Jabłońska, Tomasz Kozielec, Joanna Karbowska-Berent

Uniwersytet Mikołaja Kopernika w Toruniu, Wydział Sztuk Pięknych, Instytut Zabytkoznawstwa i Konserwatorstwa, Zakład Konserwacji Papieru i Skóry

\title{
Badania
}

\section{nad zastosowaniem celulozy bakteryjnej w konserwacji i restauracji dzieł sztuki}

\section{Uwagi wstępne}

$\mathrm{C}$ eluloza bakteryjna jest syntetyzowana przez bakterie fermentacji octowej z rodzaju Acetobacter xylinum. W warunkach hodowli stacjonarnej celuloza gromadzi się na powierzchni pożywki w formie sprężystej i elastycznej membrany. Membrana ta stanowi czystą celulozę nie zawierająca ligniny ani hemicelulozy. Celuloza bakteryjna może być łatwo modyfikowana podczas syntezy i wytwarzana w dowolnej formie i rozmiarach. Ma ona budowę krystaliczną i składa się z mikro fibryl do 100 razy mniejszych niż w celulozie roślinnej, z czym wiąże się duża zdolność przywierania do innych materiałów.

Celuloza bakteryjna jest materiałem wykorzystywanym w różnych gałęziach gospodarki. Dotychczasowe jej zastosowania objęły przede wszystkim dziedzinę medycyny ${ }^{1}$, przemysł spożywczy ${ }^{2}$ oraz kosmetyczny.

1 D. Klemm, D. Schumann, U. Udhardt, S. Marsch, Bacterial synthesized cellulose - artificial blood vessels for microsurgery, Progress in Polymer Science, vol. 26: 2001, s. 1561-1603; W. Czaja, A. Krystynowicz, S. Bielecki, R. M. Brown, Microbial cellulose - the natural power to heal wounds, Biomaterials, vol. 27: 2006, s. 145-151.

2 D. Ochaikul, K. Chotirittikrai, J. Chantra, S. Wutigornsombatkul, Studies on Fermentation of Monascus purpureus TISTR 3090 with Bacterial Cellulose from Acetobacter xylinum TISTR 967, KMITL Science Technology Journal, vol. 6, No. 1: 2006, s. 13-17. 
W przemyśle papierniczym, szczególnie w USA i Japonii opracowano wiele metod stosowania tego materiału poprawiającego wygląd i własności papierów ${ }^{3}$.

Zainteresowanie celulozą bakteryjną zbudowaną z nanowłókien celulozowych, jej nietoksyczność, biokompatybilność jak i biodegradowalność wpisuja się doskonale w światowe zainteresowania i postępy w dziedzinie nanotechnologii. Jak dotychczas celuloza bakteryjna nie znalazła praktycznego zastosowania w konserwacji zabytków. Podjęte badania w Zakładzie Konserwacji Papieru i Skóry sa pierwszymi doświadczeniami w tej dziedzinie opartymi na wykorzystaniu własności i charakterystycznych cech celulozy bakteryjnej ${ }^{4}$. W badaniach współuczestniczył Instytut Biotechnologii Technicznej Politechniki Łódzkiej, który jako jeden z kilku ośrodków na świecie wytwarza celulozę bakteryjną, zajmując się również jej badaniami oraz modyfikacjami, tworzac produkty dla celów medycznych jak również kosmetycznych i innych ${ }^{5}$.

\section{Wytwarzanie „papieru” z celulozy bakteryjnej}

Celulozę bakteryjną o określonej gramaturze w postaci membran i wysuszonych arkuszy rozdrabniano ręcznie, umieszczano w zlewce z wodą destylowaną. Całość mielono mikserem ręcznym przez określony czas do

3 B. Surma-Ślusarska, S. Presler, Danielewicz D., Characteristic of bacterial cellulose obtained from Acetobacter xylinum culture for application in papermaking, Fibers and Textiles in Eastern Europe, vol. 16, No. 4 (69): 2008, s. 108-111.

4 Praca pt. „Biotechnologia w konserwacji zabytków. Badania nad przydatnością celulozy bakteryjnej (BC) w konserwacji i restauracji dzieł sztuki" prowadzone były w latach 2008-2009 w ramach prac magisterskich i finansowane przez KBN.

5 Otrzymywanie celulozy bakteryjnej: Podłoże hodowlane $(300 \mathrm{ml})$ umieszczano w bioreaktorach o wymiarach $40 \mathrm{~cm} \times 60 \mathrm{~cm}$ i szczepiono inokulum szczepu Acetobacter xylinum. Proces biosyntezy celulozy prowadzono $\mathrm{w}$ temperaturze $30^{\circ} \mathrm{C} \mathrm{w}$ odpowiednim czasie dla uzyskania membran o gramaturze $60 \mathrm{~g} / \mathrm{m}^{2}$ i $65 \mathrm{~g} / \mathrm{m}^{2}$. Po zakończeniu biosyntezy błony celulozowe oczyszczano z związanych z nimi komórek bakterii oraz z składników podłoża hodowlanego Każdą błonę po złożeniu umieszczano w szczelnie zamkniętych pojemnikach z folii metalowej i przed przekazaniem do badań poddawano sterylizacji radiacyjnej. 
uzyskania zawiesiny o jednolitej konsystencji. W wyniku zmielenia membran oraz wysuszonych arkuszy celulozy bakteryjnej z wodą uzyskuje się trwałe i stabilne dyspersje $\mathrm{e}^{6,7}$. Zawiesiny celulozy bakteryjnej otrzymywane przez zmielenie membran i wysuszonych arkuszy BC nazywano hydrożelami. Wylewanie arkuszy wykonywano na stole niskociśnieniowym Po wstępnym odciśnięciu wody i suszeniu na stole niskociśnieniowym arkusze umieszczano pomiędzy filcami, bibułami filtracyjnymi i tekturami i umieszczano w prasie introligatorskiej do wyschnięcia.

Arkusze wylane i odsączone ze zmielonej celulozy bakteryjnej charakteryzują się wielowarstwowa, porowatą strukturą składająca się z drobnych włókien. Wyglądem otrzymane przypominaja papier.

\section{Modyfikowanie celulozy bakteryjnej (BC) dodatkiem wypełniaczy}

Wprowadzenie wypełniaczy podobnie jak ma to miejsce w produkcji papierów miało na celu poprawę własności optycznych a głównie zmniejszenie przejrzystości celulozy bakteryjnej. Zastosowano wypełniacze białe, stosowane w papiernictwie do wypełniania różnych wytworów papierniczych, oraz zmielone na bardzo drobny pył drewno sosny i brzozy. Spośród pigmentów białych, w badaniach zastosowano: tlenek glinu, dwutlenek krzemu, węglan wapnia, węglan magnezu, tlenek cynku, siarczek cynku (wykluczony podczas badań) oraz dwutlenek tytanu.

Wypełniacze wprowadzano do zmielonej celulozy bakteryjnej, z której następnie formowano arkusze ${ }^{8}$. Wprowadzano też roztwory węglanu magnezu i wapnia w postaci wodorowęglanów do (wysuszonych) arkuszy CB uzyskując efekt wypełnienia na zasadzie krystalizacji związku w ich strukturze. Używano $3 g$ wypełniacza na 1,5 litra wody nasyconej $\mathrm{CO}_{2}$. Zbadano

6 Patent JP 05051885 (1993): Disaggregation of bacterial cellulose (O. Watabe, Y. Oku).

7 Patent US 6153413 (2000): Method for processing bacterial cellulose (K. Watanabe, A. Shibata, H. Ougiya, N. Hioki, Y. Morinaga.

8 Po próbach wstępnych zastosowano proporcję $0,184 \mathrm{~g}$ wypełniacza na 2,116 g celulozy bakteryjnej (1 cz. wypełniacza/11,74 cz. CB). 
również właściwości celulozy bakteryjnej wypełnianej węglanem wapnia podczas hodowli BC (w proporcjach 10,85 g oraz 22,4 g na membranę CB) 9 .

Rozkład wypełniaczy na przekrojach analizowany technika SEM/EDX, (fot. 6-8) pozwolił na stwierdzenie zróżnicowanego rozkładu pigmentów w strukturze arkuszy. Wypełniacze gromadziły się w warstwach powierzchniowych, jak miało to miejsce w arkuszach wypełnianych podczas hodowli BC, bądź też tworzyły obok drobnych, większe skupiska cząstek. Najbardziej równomiernie rozłożony był wypełniacz w arkuszach które nasycano roztworem wodorowęglanem wapnia.

Właściwości arkuszy wypełnionych porównywano z właściwościami analogicznych arkuszy BC bez wypełnienia. Uzyskiwano arkusze o wyglądzie zbliżonym do różnych wytworów papierniczych. Podobnie jak w papiernictwie, większość wypełniaczy pogorszyła właściwości wytrzymałościowe badanego materiału. Wyjątkiem były arkusze wypełnione wypełniaczem brzozowym oraz wypełnione poprzez wprowadzenie wodorowęglanu magnezu. Celuloza bakteryjna (BC), wypełniona tlenkiem glinu wykazywała najniższą spośród badanych samozerwalność. Większość wypełnionych arkuszy BC posiadała jednak wyższą wytrzymałość w porównaniu do papieru testowego. Wyniki te sa interesujące pod względem zastosowania modyfikowanej wypełniaczami BC dla celów konserwatorskich.

Wypełniacze wpłynęły na zmianę $\mathrm{pH}$ celulozy bakteryjnej. Wartość ta najbardziej wzrosła przy wypełnieniu mielonej BC z dodatkiem węglanu magnezu oraz weglanu wapnia dodawanych podczas hodowli BC.

Tak jak się spodziewano, wypełniacze spowodowały zmiany we właściwościach optycznych. Najwyższą jasnością charakteryzowały arkusze wypełnione $\mathrm{TiO}_{2}$ oraz arkusze $z$ węglanem wapnia dodawanym podczas hodowli BC.

Dodanie zmielonego drewna obydwu gatunków do celulozy bakteryjnej wywołało jej ciemnienie z odcieniem żółtawym. Jednak jak można ocenić, uzyskano miła dla oka barwę zbliżona do pożółkłych papierów zabytkowych.

Wpływ wypełniaczy pozwolił na cenną modyfikacje właściwości optycznych celulozy bakteryjnej i potencjalnej możliwości zastosowania jej jako materiału konserwatorskiego

9 Celuloza bakteryjna wypełniana węglanem wapnia podczas hodowli wytwarzana była w Instytucie Biotechnologii Technicznej Politechniki Łódzkiej. 


\section{Badanie własności Celulozy bakteryjnej i jej modyfikacji w porównaniu do papierów testowych}

W przeprowadzonych badaniach próbki arkuszy celulozy bakteryjnej porównywano z próbkami papierów testowych z krótkich włókien bawełnianych oraz papierów ze ścieru drzewnego, kalką techniczną i papierem fotograficznym. Wszelkie zastosowane badania wytrzymałościowe membran BC, modyfikowanych arkuszy a także klejonych połączeń BC i badanymi materiałami konserwatorskimi wykonano zgodnie z Polskimi Normami dotyczącymi badań poszczególnych własności papierów i tektur przy pomocy aparatu Twing-Albert Instrument Company. Badano wytrzymałość na zerwanie określając siłę zrywającą oraz wydłużenie, wskaźnik rozciągania oraz samozerwalność, ( ISO 1924 PN-83/ P-50133, ISO 187:1990, PN-EN 20187:2000, PN-EN ISO 1924-2: 1998, PN-EN 12960: 2002, PN-EN 1895: 2004/AC). Określano także liczbę podwójnych zgięć stosując aparat Schoppera. Oznaczono masę, grubość oraz gramaturę badanych materiałów oraz zmiany tych cech pod wpływem modyfikacji. W niniejszym opracowaniu ze względu na konieczność ograniczenia objętości tekstu, przedstawiono wybrane własności badanych materiałów.

\section{Badanie pH}

Odczyn celulozy bakteryjnej zmierzony elektrodą stykową do pomiarów płaskich powierzchni był w większości badanych próbek BC lekko kwaśny. Mieścił się on w zakresie pH od wartości 5,45 do 6,50. Odczyn pH papieru testowego był wyższy i mieścił się w zakresie 6,00-6,56.

\section{Badanie własności wytrzymałościowych arkuszy celulozy bakteryjnej}

Jak wynika z przeprowadzonych badań, wpływ na odporność na zerwanie próbek BC miał sposób hodowli arkuszy oraz metoda ich suszenia. Najniż- 
sza odporność na zerwanie spośród wszystkich badanych arkuszy charakteryzuje próbkę BC W-A K (10,13 M Pa) w kierunku wzdłużnym, 5,31 MPa w kierunku poprzecznym) oraz inne arkusze BC W (17,20 $\mathrm{MPa}-22,35$ $\mathrm{MPa}$. Najwyższa wartość odporności na zerwanie cechuje próbkę BC 65 CMC-A N (89,16 MPa, 66,48 MPa w zależności od kierunku), a także pozostałe próbki z tej grupy arkuszy, z wyjątkiem próbki liofilizowanej. Najniższą odporność na zerwanie w poszczególnych grupach próbek celulozy bakteryjnej wykazuja próbki liofilizowane (8,28 MPa dla kierunku wzdłużnego próbki BC 2D-A liof) oraz próbka BC 65-A temp (9,97 MPa w kierunku wzdłużnym). Najwyższa odporność na zerwanie w każdej z grup, z wyjątkiem próbki BC W-A N, maja próbki arkuszy suszonych pod zwiększonym naciskiem.

Odporność na zerwanie niemal wszystkich badanych próbek celulozy bakteryjnej (z wyjątkiem arkuszy dwudniowej celulozy bakteryjnej i arkuszy dodatkiem węglanu wapnia podczas hodowli BC 2D - A i BC WAK) była znacznie wyższa od badanych papierów testowych.

W warunkach prowadzenia badań, celuloza bakteryjna charakteryzowała się wysoką samozerwalnością wynoszącą średnio 4538 m (dla kierunku wzdłuż krótszego brzegu arkusza) oraz średnio 4878 m (dla kierunku dłuższego brzegu arkusza). Jest ona więc wytworem posiadającym nieco większą wytrzymałość w kierunku dłuższego brzegu.

Papier testowy posiada średnią samozerwalność wynosząca $1620 \mathrm{~m}$ dla krótszego boku arkusza (kierunek poprzeczny), oraz $2554 \mathrm{~m}$ dla dłuższego kierunku arkusza (kierunek wzdłużny). Jak z powyższego wynika, samozerwalność papieru testowego jest niższa niż celulozy bakteryjnej o ok. 190\% dla próbek pobranych z kierunku poprzecznego i ok. 90\% dla próbek pobranych wzdłuż dłuższego boku. Samozerwalność arkuszy celulozy bakteryjnej zmieniała się w zależności od grupy badanych arkuszy, a także w obrębie każdej z grup i zależała od metody suszenia arkuszy.

Najniższą samozerwalność miały próbki arkuszy BC W, najwyższą arkusze BC 60 i BC 65 CMC. Wśród badanych arkuszy najniższą samozerwalność miała próbka BC 2D-A liof (1,314 km w kierunku wzdłużnym), a także inne próbki liofilizowane BC 60-A liof $(1,990 \mathrm{~km}, 1,855 \mathrm{~km}$ dla obydwu kierunków) i BC 65-A liof (odpowiednio 1,900 km i 2,222 km). Najwyższe wartości samozerwalności wykazały próbki suszone pod zwięk- 
szonym naciskiem BC 65 CMC-A N (8,285 km i 6,175 km) i BC 65-A N $(6,037 \mathrm{~km}$ i $5,398 \mathrm{~km})$.

\section{Sklejanie i dublaże arkuszy celulozy bakteryjnej i papieru testowego $\mathrm{z}$ udziałem klejów i hydrożeli z zmielonej celulozy bakteryjnej}

Jako materiał do dublażu zastosowano arkusze celulozy bakteryjnej o gramaturze $60 \mathrm{~g} / \mathrm{m}^{2}$ i papier testowy. Próbki papierów i arkuszy celulozy bakteryjnej sklejano ze sobą na całej powierzchni każdym z badanych klejów. Klejami tymi były: 1\% metyloceluloza, klej skrobiowy z metylocelulozą 1\% (2:1), klej akrylowy, zmielona celuloza bakteryjna dwudobowa (nazywana w badaniach hydrożelem) oraz klej jak powyżej modyfikowany 1\% metyloceluloza. W trakcie przebiegu dublowania obserwowano zachowanie dublowanego papieru testowego i arkuszy celulozy bakteryjnej, a następnie efekt dublowania. Po zwilżeniu klejem arkusze BC nakładano na papier testowy. Nie zaobserwowano trudności związanych ze ślizganiem się warstw materiałów, ani z ich deformacja.

Wytrzymałość na zerwanie (obciążenie zrywające) arkusza celulozy bakteryjnej jest prawie 4,4 razy wyższa niż papieru testowego. Po sklejeniu ze sobą materiałów w przypadku wszystkich klejów siła [N] potrzebna do zerwania próbek była ponad dwukrotnie większa niż arkusza celulozy bakteryjnej, a odporność na zerwanie wyższa niż papieru testowego, ale niższa niż arkusza celulozy bakteryjnej. Najbardziej wytrzymałe na zerwanie były dublaże wykonane przy użyciu kleju skrobiowego z metylocelulozą (37,115 $\mathrm{MPa}$, najmniej sklejone za pomocą hydrożelu z II-dobowego arkusza celulozy bakteryjnej modyfikowanego 0,25\% metylocelulozą (22,530 MPa). Pozostałe kleje zastosowane do dublażu takie jak akrylowy, metyloceluloza, 1\% i hydrożel z II-dobowego arkusza celulozy bakteryjnej, wykazały zbliżoną do siebie odporność na zerwanie (około $30 \mathrm{MPa}$ ).

Wskaźnik rozciagania $[\mathrm{Nm} / \mathrm{g}]$ przy zerwaniu arkusza celulozy bakteryjnej $(46,519 \mathrm{Nm} / \mathrm{g}$ ) był ponad dwukrotnie wyższy niż papieru testowego $(22,095 \mathrm{Nm} / \mathrm{g})$. Wartość rozciagania przy zerwaniu próbek sklejonych różnymi klejami, z wyjątkiem kleju akrylowego, uległa obniżeniu w porów- 
naniu z samym arkuszem celulozy bakteryjnej, ale wzrosła w porównaniu z papierem testowym. Najbardziej elastyczny jest klej akrylowy, którego wskaźnik rozciagania w przypadku dublaży wyniósł 59,078 Nm/g. Z pozostałych klejów również wysoką wartość zanotowano dla kleju skrobiowego modyfikowanego metylocelulozą (42,583 Nm/g). Najmniejszy wpływ na podwyższenie wskaźnika rozciagania miało zastosowanie jako spoiwa hydrożeli z II-dobowego arkusza celulozy bakteryjnej (wyniósł on 32,239 $\mathrm{Nm} / \mathrm{g}$ dla hydrożelu z II-dobowego arkusza i 31,989 dla hydrożelu modyfikowanego metyloceluloza).

Wszystkie zbadane dublaże z wykorzystaniem arkusza celulozy bakteryjnej jako nośnika wpływają na podwyższenie własności wytrzymałościowych papieru testowego. Klej skrobiowy spowodował usztywnienie i kruchość arkuszy. Zwłaszcza arkusze celulozy bakteryjnej II-dobowej po nałożeniu warstwy kleju skrobiowego posiadały większą tendencję do pękania, przełamywania i zwijania, a ich rozprostowanie bez powtórnego nawilżenia nie było możliwe. Nawet po nawilżeniu i wyprostowaniu, arkusze na wolnym powietrzu wykazywały silną tendencję do odkształcania. Powierzchnia arkuszy celulozy bakteryjnej z nałożoną warstwa kleju była matowa, chropowata, z wyraźnymi śladami pędzla.

Metyloceluloza spowodowała zwiększenie połysku arkuszy celulozy bakteryjnej. Strona matowa z nałożoną warstwą kleju przypominała warstwę błyszczaca przed nałożeniem kleju. W trakcie wysychania powłok z metylocelulozy widoczna była opalizacja arkuszy. Wysuszone arkusze były gładkie, nie zaobserwowano też większych odkształceń powierzchni.

Powłoka z hydrożelu ze zmielonej celulozy bakteryjnej nie była widoczna na arkuszach, a można ja było rozpoznać jedynie po lekkim zmatowieniu powierzchni. Zawiesina włókien hydrożelu osadzała się nierównomiernie na obu sklejanych powierzchniach.

Siła oddzierająca próbek w których do połączenia materiału zastosowano hydrożele ze zmielonej celulozy bakteryjnej, była tylko nieco niższa od kleju akrylowego (i wyniosła 2,0 N i 1,8 N), ale znacznie wyższa od metylocelulozy 1\%(0,7 N). Próbki w których zastosowano hydrożele ze zmielonej celulozy bakteryjnej uległy zerwaniu po dwóch minutach oddzierania, czyli znacznie szybciej niż próbki sklejone klejem akrylowym. Dodatek metylocelulozy do hydrożelu ze zmielonej celulozy bakteryjnej wzmocnił si- 
łę klejenia tylko w niewielkim stopniu. Wartości odporności na zerwanie $\mathrm{P}$ są najwyższe w wypadku kleju skrobiowego, a najniższe dla metylocelulozy.

Nałożone pędzlem zawiesiny włókien celulozy bakteryjnej tworzą na powierzchni papieru testowego bardzo cienkie, przezroczyste i lekko połyskujące powłoki. Warstwa celulozy bakteryjnej jest czytelna i wyraźnie widoczna pod mikroskopem optycznym. Zmielone włókna celulozy bakteryjnej wysychając łączą się ze sobą i tworzą na powierzchni papieru cienka, ścisła błonę o budowie warstwowej. Powłoka mocno przylega do papieru testowego, a jego powierzchnia staje się gładka i połyskliwa. Niekiedy małe skupiska włókien celulozy bakteryjnej osadzają się pomiędzy włóknami papieru testowego.

Najlepsze błony, bez wyraźnych śladów pędzla, dawały hydrożele zmielone z arkuszy celulozy bakteryjnej II-dobowej. Dodatek metylocelulozy pozytywnie wpłynął na właściwości zawiesiny. Już niewielki dodatek metylocelulozy do zmielonej celulozy bakteryjnej poprawił w znacznym stopniu smarowność, a hydrożel rozprowadzał się znacznie łatwiej i bardziej równomiernie na powierzchni papieru. Celuloza bakteryjna nie tworzy równomiernej warstwy przy powlekaniu powierzchni arkusza papieru. Podobne trudności w nakładaniu zawiesiny włókien celulozy bakteryjnej na powierzchnię arkusza zauważono w przypadku użycia powlekarek ${ }^{10}$.

\section{Uzupełnianie ubytków w papierze, pergaminie, skórze i tkaninach płynnymi masami \\ zawierającymi zawiesiny celulozy bakteryjnej}

Celem wykonanych badań było zastosowanie celulozy bakteryjnej do uzupełniania ubytków w różnorodnych materiałach spotykanych w obiektach zabytkowych. Wybranymi materiałami były: papier ręcznie czerpany, maszynowy, kalka techniczna, tkaniny takie jak płótno lniane, tkanina jedwabna o splocie płóciennym i atłasowym a także pergamin obustronnie

\footnotetext{
10 Patent US 5637197 (1997): Process of coating a substrate with reticulated bacterial cellulose aggregates (W. Watt, T. Adams, G. Peterson, R. Stephens, J. Askew).
} 
szlifowany oraz skóra. Jako masę uzupełniającą ubytki w wymienionych podłożach zastosowano zawiesiny celulozy bakteryjnej uzyskane w wyniku zmielenia wysuszonych arkuszy oraz masy stanowiace mieszaniny zmielonej BC i włókien naturalnych odpowiednio dobranych do uzupełnianego materiału.

Uzupełniano mniejsze uszkodzenia mechaniczne wymienionych materiałów jak i większe nieregularne ubytki. Zastosowano trzy metody uzupełniania a mianowicie, metodę mokra za pomocą mas płynnych, metodę półsuchą za pomoca mas półpłynnych oraz metodę suchą, polegająca na wklejaniu łatek, przygotowanych po wysuszeniu płynnych mas, za pomoca odpowiednio dobranego spoiwa.

\section{Uzupełnianie papierów}

Na stole niskociśnieniowym umieszczono arkusz włókniny, a na nim ułożono uzupełniany materiał, który następnie silnie zwilżono wodą i wygładzano w celu usunięcia pęcherzyków powietrza. Stół przykryto folią estrafolowa, pozostawiając odsłonięte jedynie miejsca ubytków. Papier uzupełniano od strony odwrocia, nakładając masy cienkimi warstwami, za pomoca łyżeczki lub łopatki dentystycznej. Nakładano kolejno kilka warstw masy. Nałożone warstwy nachodziły lekko na krawędzie uszkodzenia. Uzupełnianie przeprowadzano do momentu w którym osiagnięto grubość zbliżoną do materiału uzupełnianego. Ostatnią warstwę wyrównywano i wygładzano kostką introligatorską. Gdy masy stały się zwarte, a ich powierzchnie matowe, całość przykryto włókniną i odsysano na stole niskociśnieniowym na czas ok. 10-15 minut. Celem było podsuszenie i sprasowanie uzupełnień, umożliwiające ich lepsze połączenie $z$ oryginałem. Uzupełniony materiał ułożono między suchymi włókninami, bibułami filtracyjnymi oraz tekturami i umieszczono do wyschnięcia pod obciążeniem w prasie na ok. 2-3 dni. W tym czasie kila razy wymieniano wilgotne bibuły filtracyjne i tektury na suche. Zaleta płynnych mas z dodatkiem celulozy bakteryjnej, jak i samej zawiesiny celulozowej jest ich bardzo dobra adhezja do podłoża, dzięki cze$\mathrm{mu}$ nie wymagaja one stosowania spoiwa. Uzupełnienia charakteryzuje lekko żółtawa, naturalna barwa zbliżona do zabytkowych papierów, szczególnie maszynowego. Ich elastyczność jest zbliżona do uzupełnianego materiału. 


\section{Uzupełnianie tkanin}

Proces uzupełniania tkanin przeprowadzono w sposób analogiczny do uzupełniania ubytków w papierze. Proces uzupełniania trwał ok. 1-1,5 godziny. Czas trwania zabiegu zależał od wielkości i grubości uzupełnienia. Po tym czasie uzupełniony materiał ułożono między suchymi włókninami, bibułami filtracyjnymi oraz tekturami i pozostawiono do wyschnięcia pod obciążeniem w prasie introligatorskiej na około 2-3 dni. W tym czasie kila razy wymieniano wilgotne bibuly i tektury na suche.

\section{Metoda półsucha}

Metodę półsuchą zastosowano do uzupełniania pergaminu i skóry. Uzupełnianie przebiegało z wykorzystaniem stołu niskociśnieniowego, co umożliwiało nieprzerwane odsączanie nadmiaru wody z mas uzupełniających. Zabieg uzupełniania półsuchymi masami składał się z trzech etapów:

- I etap - podsuszanie płynnych mas na stole niskociśnieniowym Masy formowano na włókninie, ułożonej bezpośrednio na stole niskociśnieniowym, za pomocą ramki ze styropianu do wnętrza której wlewano warstwowo płynne zawiesiny. Czekano, aż nadmiar wody zostanie z nich usunięty i dolewano kolejna porcję (k. 3-5 razy).

Podczas zabiegu stół był przykryty folia z wyjątkiem miejsca, w którym znajdowało się okno ramki. Formowano masy zbliżone do grubości materiałów uzupełnianych, o wymiarach nieco większych niż ubytek. W zależności od wymaganej grubości mas uzupełniających podsuszanie trwało ok. 2-3 godzin. Po uzyskaniu odpowiedniej gęstości uzupełnienia i dobrej przyczepności do uzupełnianego materiału, ramkę usuwano a krawędzie uformowanej masy wyrównywano kostką introligatorską

- II etap - uzupełnianie ubytków półsuchymi masami

$\mathrm{Na}$ stole niskociśnieniowym uzyskanymi półsuchymi masami wypełniono miejsca ubytków od strony odwrocia materiału uzupełnianego, umieszczonego na warstwie bibuł filtracyjnych oraz włókninie. Po czym całość zabezpieczono od lica arkuszem włókniny, przykryto 
estrafolem i prasowano na stole niskociśnieniowym ok. 15 minut w celu połączenia masy z materiałem uzupełnianym.

- III etap - suszenie uzupełnionego materiału pod obciążeniem w prasie Po zdjęciu uzupełnionego materiału ze stołu, ułożono go między suche włókniny, bibuły filtracyjne oraz tektury i umieszczono w prasie na czas ok. 7-9 dni w przypadku pergaminów i ok. 5-7 dni w przypadku skór. W tym czasie bardzo często wymieniano wilgotne bibuły filtracyjne oraz tektury na suche.

\section{Metoda sucha}

Metoda sucha polegała na wklejaniu łatek przygotowanych z arkusików powstałych po wysuszeniu płynnych mas. Zastosowano ją do uzupełnienia pergaminu i skóry.

W pergaminie $\mathrm{nr} 1$, łatki przyklejano $5 \%$ klejem pergaminowym, w pergaminie nr 2 zastosowano $5 \%$ klej rybi.

W skórze nr 1, łatki przyklejano - 12\% klejem króliczym, w skórze nr 2, łatki przyklejano klejem akrylowym Lascaux $498 \mathrm{HV}$.

Przed wklejeniem uzupełnień krawędzie ubytków i łatek ścieniono na szerokość ok. 2-3 mm. Latkę przyklejono od strony odwrocia materiału, a następnie wygładzono i mocno przyciśnięto kostka introligatorska. Uzupełniony materiał ułożono między arkuszami włóknin i suszono pod niewielkim obciążeniem. Końcowym etapem po wyschnięciu uzupełnień było opracowanie krawędzi łatek, które ścieniono i wyrównano za pomocą skalpela.

Technika suchą uzupełniano ubytki w pergaminach za pomoca arkuszy przygotowanych z trzech rodzajów mas: włókna pergaminowe $+\mathrm{BC}(3: 1)$; (1:1); (3:1), zawiesina celulozy bakteryjnej oraz włókna bawełniane $+\mathrm{BC}$ (1:3); (1:1); (3:1).

W skórze uzupełniano powierzchniowe ubytki lica oraz ubytki występujące w całej jej grubości. Uszkodzenia powierzchniowe, uzupełniono cienkim arkuszem, odpowiednio przyciętym do wymiarów i kształtu ubytku. Latki o fazowanych krawędziach przyklejono w uszkodzone miejsca metodą „na styk”. 
Ubytki występujące w całej grubości skóry uzupełniono dwoma cienkimi arkuszami, wklejonymi warstwowo, tak aby uzyskać grubość zbliżoną do grubości skóry. Opracowano dwie łatki, z których jedna była nieco większa od ubytku, natomiast wymiary drugiej dokładnie odpowiadały wielkości uszkodzenia. Krawędzie obu łatek były fazowane na szerokość ok. 2-3 mm. W pierwszej kolejności wklejano większą łatkę, od strony mizdry następnie od strony lica skóry wklejono drugą łatkę metoda „na styk”, tworząc drugą warstwę uzupełnienia.

Wykorzystując plastyczne i elastyczne właściwości zawiesiny celulozy bakteryjnej i mas z jej dodatkiem w stanie półsuchym, wykonano próby fakturowania ich powierzchni. Najdokładniej faktura w postaci negatywu splotu płóciennego odbiła się $\mathrm{w}$ próbce utworzonej z zawiesiny celulozy bakteryjnej (fot 10) a oraz w próbkach wykonanej z mas z dużym jej dodatkiem. Utrzymanie faktury powierzchni jest trwałe po wyschnięciu masy.

\section{Badania nad zwiększeniem odporności mikrobiologicznej BC}

Celem badań było zwiększenie odporności celulozy bakteryjnej na atak mikrobiologiczny za pomoca preparatów biobójczych.

Do zabezpieczenia przed atakiem mikrobiologicznym BC wybrano trzy preparaty:

a. prototypowy preparat L-2 (zawierający 15\% chlorku didecylodimetyloamoniowego i 3\% bis (aminopropylo)dodecyloaminy),

b. S-30 (30\% wodny roztwór 2-fenylofenolan sodu),

c. NPS (alkohol etylowy + srebro w postaci nanoczasteczek).

Preparaty wprowadzano poprzez zanurzenie arkuszy $\mathrm{BC} w$ roztworach dezynfekujących. Po wyschnięciu arkusze zakażano zawiesinami szczepów grzybów j.w. lub poddano działaniu drobnoustrojów z powietrza. Wszystkie próbki umieszczono w komorach wilgotnych w temperaturze $25^{\circ} \mathrm{C}$ na 3 miesiące.

Preparaty L-2 (w stężeniu 0,5\% związku aktywnego) i S-30 (w stężeniu $0,3 \%$ związku aktywnego) okazały się wystarczająco skuteczne do zabezpieczania celulozy bakteryjnej przed atakiem grzybów (w nieco mniej- 
szym stopniu wobec Trichoderma pseudokoningii). Preparat nanosrebrowy NPS - 200 (w stężeniu 20 ppm) okazał się całkowicie nieskuteczny.

\section{Wnioski}

Analizy mikroskopowe (SEM, ESEM, AFM) wykazały duże różnice w budowie strukturalnej między papierem testowym oraz celuloza bakteryjna (CB). CB jest wytworem wielowarstwowym w przeciwieństwie do papieru testowego. Składa się z dużej ilości bardzo drobnych warstewek zbudowanych z siatki mikrofibryl, których grubość wynosi najczęściej kilkadziesiąt nanometrów (najczęściej nie przekracza $100 \mathrm{~nm}$ ). Dla porównania włókna celulozowe mają nieporównywalnie większe wymiary rzędu średnio kilkunastu $\mu \mathrm{m}$. CB jest materiałem o dużej gładkości i tworzywem bardzo zwartym o niskiej przepuszczalności powietrza i pary wodnej.

Włączenie celulozy bakteryjnej do badań konserwatorskich poprzedzające jej praktyczne zastosowanie w konserwacji zabytków okazało się cenna idea.

Badania właściwości celulozy bakteryjnej, obserwacja wyglądu i powierzchni wysuszonych arkuszy potwierdziły możliwość wykorzystania celulozy bakteryjnej do prac konserwatorskich, jednak z koniecznym zastrzeżeniem modyfikacji tego produktu. Korzystną modyfikacja jest zmielenie wysuszonych arkuszy celulozy bakteryjnej.

Zbadane właściwości klejące hydrożeli wykazały, że mogą one zostać wykorzystane jako spoiwo. Zawiesiny włókien celulozy bakteryjnej użyte do sklejania próbek papierów i bibułki jednocześnie je wzmacniały. Nieduża siła klejenia hydrożeli może być zaletą w wypadku, gdy konieczne jest wykorzystanie kleju o spoinie słabszej niż sklejane materiały.

Korzystna cechą płynnych mas na bazie celulozy bakteryjnej jest ich wysoka adhezja do podłoża dzięki czemu moga być one stosowane bez dodatku spoiwa.

Dodatek białych pigmentów oraz zmielonego drewna jako wypełniaczy poprawiało własności optyczne a także $\mathrm{pH}$ arkuszy utworzonych z zawiesiny BC. Arkusze takie zyskiwały duże podobieństwo do papierów.

Zawiesiny celulozy bakteryjnej mieszały się dobrze z włóknami tkanin, pergaminu i skóry pozwalając na uzyskanie dobrych i elastycznych materiałów do uzupełnienia ubytków w różnorodnych materiałach. 


\section{Literatura}

Czaja W., Krystynowicz A., Bielecki S., Brown R. M., Microbial cellulose - the natural power to heal wounds, Biomaterials, Vol. 27: 2006

Jabłonskaja I., Zastosowanie różnych wypełniaczy do modyfikacji celulozy bakteryjnej, praca mgr, maszynopis, Toruń 2009

Klemm D., Schumann D., Udhardt U., Marsch S., Bacterial synthesized cellulose - artificial bloodvessels for microsurgery, Progress in Polymer Science, Vol. 26: 2001, s. 1561-1603

Kowaczew J., Uzupełnianie ubytków w materiałach (papier, tkanina, pergamin, skóra) płynnymi masami na bazie bakteryjnej celulozy, praca mgr, maszynopis, Toruń 2009

Myślicka M., Celuloza bakteryjna. Możliwość zastosowania do wzmacniania papieru poprzez podklejanie, dublaż i powlekanie. Barwienie celulozy bakteryjnej, praca mgr, maszynopis, Torun 2009

Ochaikul D., Chotirittikrai K., Chantra J., Wutigornsombatkul S., Studies on Fermentation of Monascus purpureus TISTR 3090 with Bacterial Cellulose from Acetobacter xylinum TISTR 967, KMITL Science Technology Journal, Vol. 6, No. 1: 2006, s. 13-17

Patent JP 05051885 (1993): Disaggregation of bacterial cellulose (O. Watabe, Y. Oku) Patent US 6153413 (2000): Method for processing bacterial cellulose (K. Watanabe, A. Shibata, H. Ougiya, N. Hioki, Y. Morinaga

Patent US 5637197 (1997): Process of coating a substrate with reticulated bacterial cellulose aggregates (W. Watt, T. Adams, G. Peterson, R. Stephens, J. Askew)

Surma-Ślusarska B., Presler S., Danielewicz D., Characteristic of bacterial cellulose obtained from Acetobacter xylinum culture for application in papermaking, Fibers and Textiles in Eastern Europe, Vol. 16, No. 4 (69): 2008

Witkowski M., Wpływ suszenia na wygląd i własności celulozy bakteryjnej, praca mgr, maszynopis, Toruń 2010

\section{Summary}

\section{Study on the use of bacterial cellulose in the conservation and restoration of works of art}

Bacterial cellulose (BC) obtained in the bacterial biosynthesis by Acetobacter xylinum is considered one of the most interesting materials tested and used in differ- 
ent areas of the human activity. Successful its applications in medicine and food industry launched a study of this material on a large scale. Many characteristic and unique properties of bacterial cellulose are used already in the paper industry Research and application of bacterial cellulose nano fibers made up of cellulose, its non-toxic, biocompatibility and biodegradability fit perfectly into the world of interest and progress in nanotechnology. Plant cellulose and bacterial cellulose have the same chemical structure, but different chemical and physical properties. Bacterial Cellulose is biopolymer not soluble, more elastic and demonstrate a high tensile strength.

The study was performed in collaboration with the Institute of Technical Biochemistry, Technical University of Lódź. Planned and carried out the study covered a wide range of experience of testing the applicability of bacterial cellulose as well as its modification in the work of restoration. So far, studies and practical adaptation of bacterial cellulose in our research are the first tests in the conservation area. The exceptions were the addition of bacterial cellulose sample during the manufacture of paper hand-derived, which as noted have a positive impact on the properties of paper produced and lead to the conclusion that the paper with the participation of bacterial cellulose can be used for archival and preservation purposes. Research undertaken in this study are the first extensive experience seeking to use the unique properties of this material such as high strength and elasticity, content of pure cellulose with a high degree of polymerization and the ability of these material to modification.

Microscopic analysis (SEM, ESEM, AFM) showed significant differences in the structural construction of the test paper and bacterial cellulose (BC). BC is a product of a multi-layered as opposed to a paper test. It consists of a large number of very fine mesh of layers made of the microfibrils, whose thickness is usually tens of nanometers (usually less than $100 \mathrm{~nm}$ ). Preliminary studies of bacterial cellulose membranes indicated the need to modify the native membrane by drying them to form sheets, and further grinding in the presence of water. Suspensions of bacterial cellulose known in our work hygrogels were modified with the addition of fillers, dyes, methyl cellulose, fibers of paper, fabric and dry shredded leather and parchment. The obtained hydrogels were characterized by low density and high water content, which allowed the formation of thin coats or seams. Additive methylcellulose had a positive influence on the properties of suspensions and coats. Structure of the sheets turned out by use the hydrogels was in contrast to the less dense sheets of $\mathrm{BC}$ a more flexible and bibulous.

These suspensions were poured on the low-pressure suction table create flexible, durable sheets with similar appearance to the materials, which were the source 
fiber supplements. Hydrogels blended well with the fibers of fabrics, leather and parchment response for good and flexible materials. A significant advantage of bacterial cellulose is easy given to maintaining its forms such as impress of the sieve or cloth texture and others.

Sheets of bacterial cellulose, its suspension were used as a bonding agent to reinforcing by coating and lining of test paper. Adhesive properties of hydrogels demonstrated that they can be used as a bonding mediums. Suspensions of bacterial cellulose fibers made from various materials were used for filling the holes in paper, textiles, leather and parchment. Lining samples of Bacterial cellulose sheets did not show any tendency to cracking and tearing. The test paper lining on sheet of $\mathrm{BC}$ strengthened the

mechanical properties of the test paper. Suspensions of bacterial cellulose fibers used for coating the test paper and tissue samples delicate reinforcing them. Positive effect of application dried sheets to restoration of old photos, application of modified hydrogels to filling and reinforcing the paper and others tested treatment indicate necessary to continue of the evaluation on these field.

Study were performed a wide range of experience. By microscopy examination (SEM, ESEM, OTC) was identified the morphology and structure of the membranes, any modified sheets and products. Colorimetrically determined by the brightness and colors of tested materials. $\mathrm{PH}$ and mechanical properties of the membranes, modified sheets and adhesive bonded joints to conservation materials was tested according to Polish standards. Determined mass, thickness, basis weight of the bio-cellulose materials and their changes under influence of the modification applied. Researched the optimal methods of membranes and modified sheets drying. Determined the rate of water vapour transmission according to Polish standards. It was made also evaluation of hygro-stability of the biocellulosic sheets. Biocellulose and test paper changes were studied under the influence of accelerated ageing. The results of investigation indicated that Bacterial Cellulose was more sensitive to microbial attack than the test paper. This characteristic can be improved by application of biocides. 


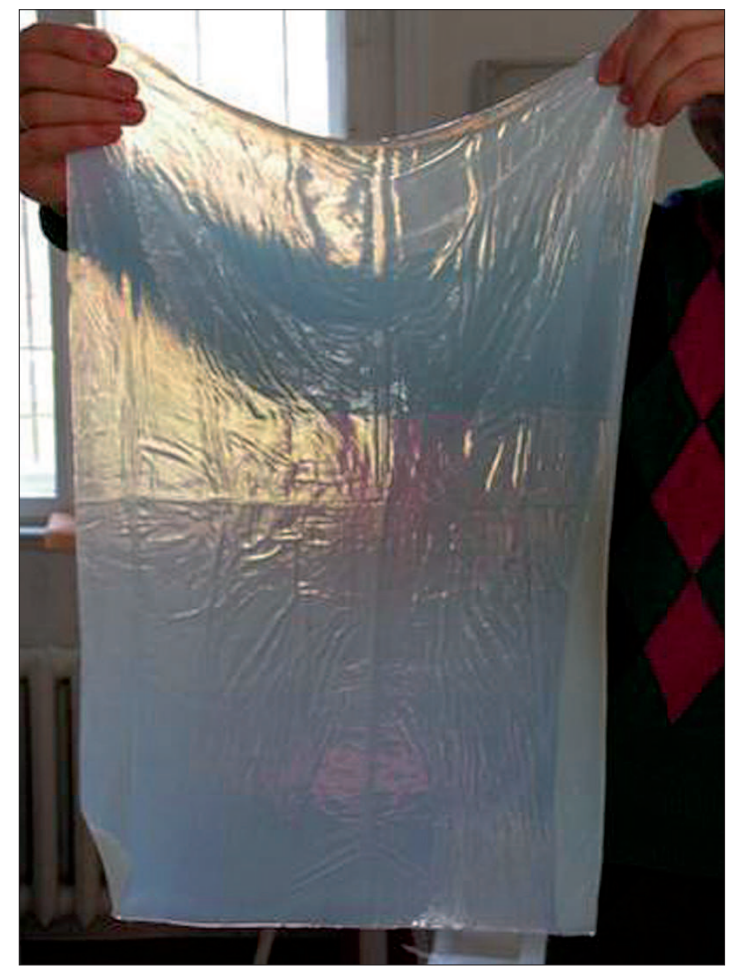

Il. 1. Wygląd membrany celulozy, fot. M. Witkowski

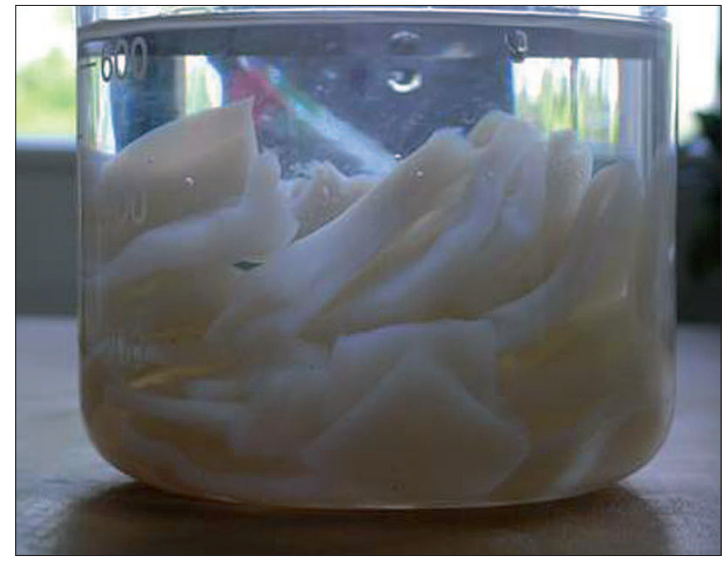

Il. 2. Membrana BC przygotowana do zmielenia, fot. M. Witkowski 


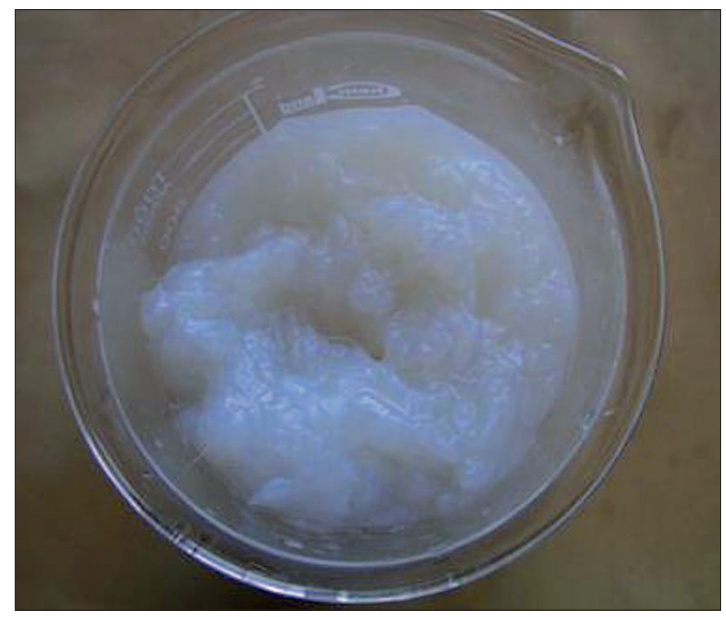

Il. 3. $\mathrm{BC}$ w trakcie mielenia, bakteryjnej, fot. M. Witkowski

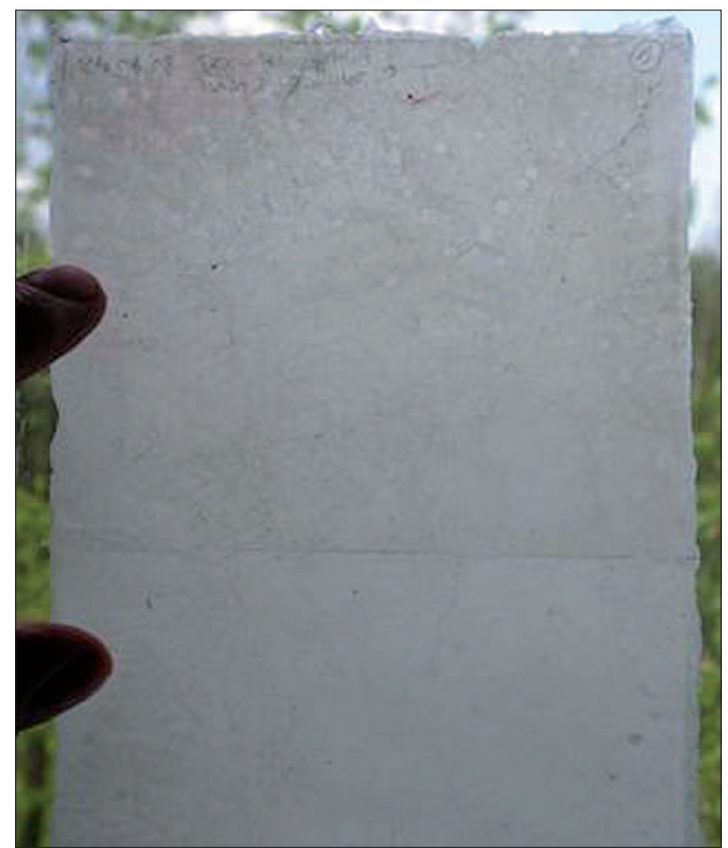

Il. 4. Arkusz uzyskany z zmielonej BC (zawiesiny włókien $\mathrm{BC}$ ), fot. M. Witkowski 


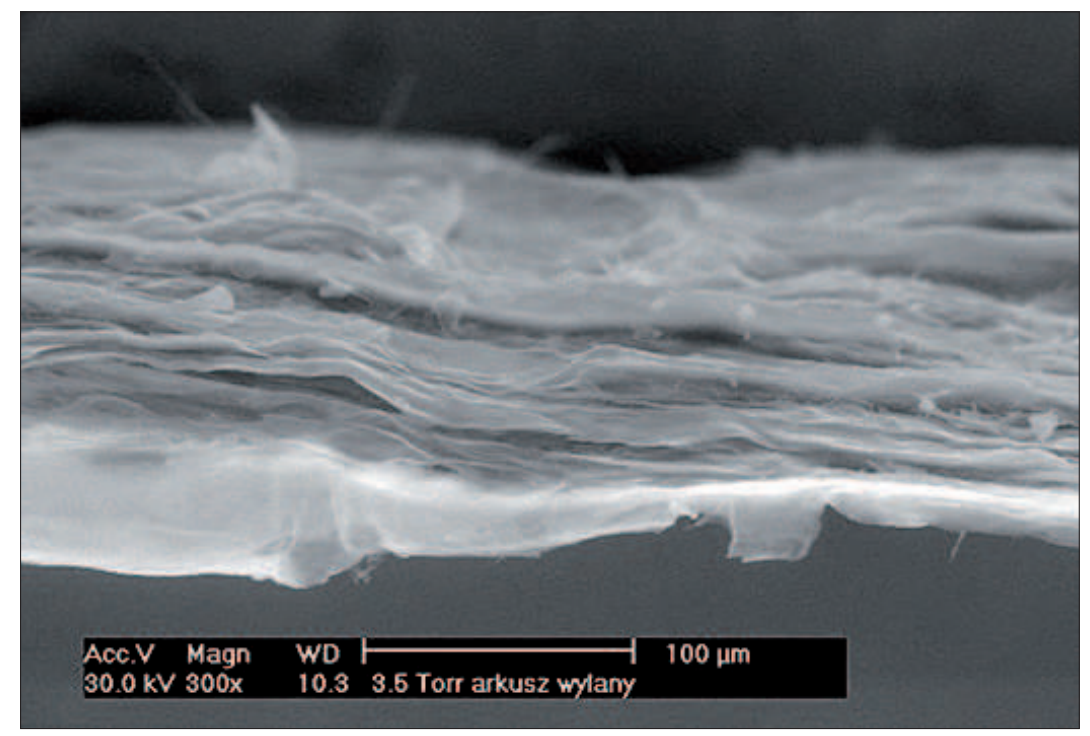

Il. 5. Warstwowa struktura arkusza wylanego ze zawiesiny włókien celulozy bakteryjnej (ESEM pow. 300×, fot. J. Stryjewski, Katedra Inżynierii Materiałowej, Wydział Mechaniczny Politechniki Gdańskiej)

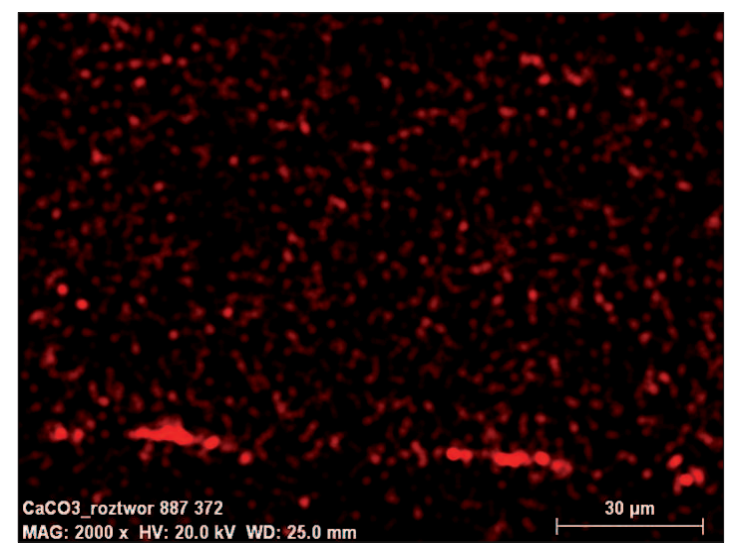

Fot. 6. Nie mielony arkusze z celulozy bakteryjnej $\mathrm{z} w$ prowadzonym roztworem węglanu wapnia (CaCO3 r-r), 2000×, fot. Grzegorz Trykowski, Pracownia Analiz Instrumentalnych, Wydział Chemii, UMK 


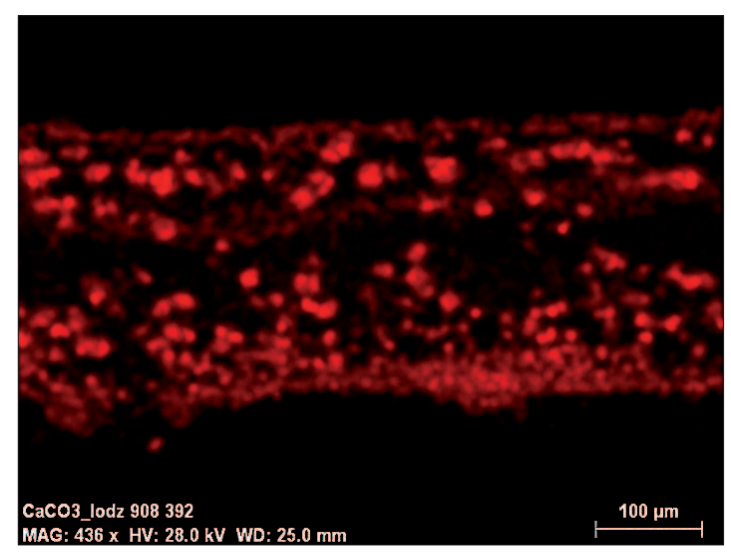

Il. 7. Celuloza bakteryjna modyfikowana węglanem wapnia $(\mathrm{CaCO} 3)$ na etapie hodowli 436x, fot. Grzegorz Trykowski, Pracownia Analiz Instrumentalnych, Wydział Chemii, UM

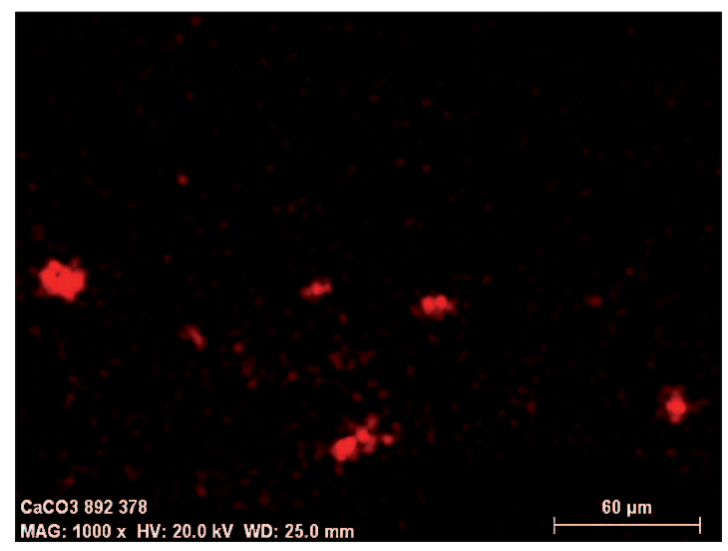

Fot. 8. Mielona celuloza bakteryjna modyfikowana węglanem wapnia (CaCO3), 1000×, fot. Grzegorz Trykowski, Pracownia Analiz Instrumentalnych, Wydział Chemii, UM 
Tab. 1. Rodzaje papierów testowych

\begin{tabular}{|c|c|}
\hline Wytwory papiernicze & Rodzaj próbki \\
\hline $\begin{array}{l}\text { Papier testowy z lintersów bawelnianych, bez } \\
\text { wypelniaczy, nie przeklejony, w składzie papieru } 95 \% \\
\text { bawelny i } 5 \% \text { masy celulozowej z drzew iglastych, } \\
\text { Cotton linters cellulose paper, prod. Papierfabrik } \\
\text { Schutt Heelsum, The Netherlands }\end{array}$ & Papier testowy B / PT B \\
\hline $\begin{array}{l}\text { Papier testowy z wypelniaczem kaolinowym ( } 20 \%) \text {, } \\
\text { przeklejony żywicą z ałunem, w składzie papieru } 75 \% \\
\text { ścieru drzewnego i } 25 \% \text { masy celulozowej z drzew } \\
\text { iglastych, Groundwood containing paper, prod. } \\
\text { Papierfabrik Schutt Heelsum, The Netherlands }\end{array}$ & Papier testowy W / PT W \\
\hline $\begin{array}{l}\text { Kalka techniczna } 90 / 95 \mathrm{~g} / \mathrm{m}^{2} \text { Calque Satin Canson } \\
12125 \text {, prod. Papeteries Canson \& Montgolfier S. A. } \\
\text { France }\end{array}$ & Kalka techniczna / KT \\
\hline $\begin{array}{l}\text { Papier fotograficzny Foma N 311, prod. Bohemia spol. } \\
\text { s. r. o. } 50104 \text { Hradec Králové, Czech Republic }\end{array}$ & Papier fotograficzny / PF \\
\hline
\end{tabular}


Tab. 2. Rodzaje celulozy bakteryjnej wykorzystanej w badaniach

\begin{tabular}{|c|c|}
\hline $\begin{array}{c}\text { Celuloza bakteryjna } \\
\end{array}$ & Rodzaj próbki \\
\hline $\begin{array}{l}\text { Celuloza bakteryjna } \mathrm{z} \text { hodowli dwudobowej w formie } \\
\text { membrany (M) lub wysuszonego arkusza w prasie (A) }\end{array}$ & $\begin{array}{l}\text { BC 2D-M } \\
\text { BC 2D-A }\end{array}$ \\
\hline $\begin{array}{l}\text { Celuloza bakteryjna } z \text { hodowli dwudobowej w formie arkusza } \\
\text { wysuszonego w liofilizatorze (A) }\end{array}$ & BC 2D-A liof / L \\
\hline $\begin{array}{l}\text { Celuloza bakteryjna } 60 \mathrm{~g} / \mathrm{m}^{2} \text { w formie membrany (M) lub } \\
\text { wysuszonych arkuszy (A) }\end{array}$ & $\begin{array}{l}\text { BC 60-M } \\
\text { BC 60-A }\end{array}$ \\
\hline $\begin{array}{l}\text { Celuloza bakteryjna } 60 \mathrm{~g} / \mathrm{m}^{2} \text { suszona w prasie introligatorskiej } \\
\text { po wyciśniecciu wody pod ruchomym obciazzeniem }\end{array}$ & BC 60-A R \\
\hline $\begin{array}{l}\text { Celuloza bakteryjna } 60 \mathrm{~g} / \mathrm{m}^{2} \text { suszona w prasie hydraulicznej } \\
\text { pod zwiększonym obciążeniem } 4.5 \mathrm{~T}\end{array}$ & BC 60-A N \\
\hline $\begin{array}{l}\text { Celuloza bakteryjna } 60 \mathrm{~g} / \mathrm{m}^{2} \mathrm{w} \text { formie arkusza wysuszonego } \mathrm{w} \\
\text { liofilizatorze }\end{array}$ & BC 60-A liof \\
\hline $\begin{array}{l}\text { Celuloza bakteryjna } 65 \mathrm{~g} / \mathrm{m}^{2} \text { w formie membrany (M) lub } \\
\text { wysuszonych arkuszy (A) }\end{array}$ & $\begin{array}{l}\text { BC 65-M } \\
\text { BC 65-A }\end{array}$ \\
\hline $\begin{array}{l}\text { Celuloza bakteryjna } 65 \mathrm{~g} / \mathrm{m}^{2} \mathrm{w} \text { formie wysuszonych arkuszy } \\
\text { (A) próbki kontrolne }\end{array}$ & $\begin{array}{l}\text { BC 65-A K1 } \\
\text { BC 65-A K2 } \\
\text { BC 65-A K3 } \\
\end{array}$ \\
\hline $\begin{array}{l}\text { Celuloza bakteryjna } 65 \mathrm{~g} / \mathrm{m}^{2} \text { suszona w suszarce komorowej } \\
\text { w temperaturze } 40^{\circ} \mathrm{C}\end{array}$ & BC 65-A temp / T \\
\hline $\begin{array}{l}\text { Celuloza bakteryjna } 65 \mathrm{~g} / \mathrm{m}^{2} \text { suszona na siatce serigraficznej } \\
\text { pod lekkim obciązeniem (deska do prasy introligatorskiej) }\end{array}$ & BC 65-A S \\
\hline $\begin{array}{l}\text { Celuloza bakteryjna } 65 \mathrm{~g} / \mathrm{m}^{2} \text { suszona w prasie hydraulicznej } \\
\text { pod zwiększonym obciazzeniem } 4.5 \mathrm{~T}\end{array}$ & BC 65-A N \\
\hline $\begin{array}{l}\text { Celuloza bapkteryjna } 65 \mathrm{~g} / \mathrm{m}^{2} \text { w formie arkusza wysuszonego } \\
\text { w liofilizatorze }\end{array}$ & BC 65-A liof / L \\
\hline $\begin{array}{l}\text { Celuloza bakteryjna } 65 \quad \mathrm{~g} / \mathrm{m}^{2} \text { hodowana w obecności } \\
\text { karboksymetylocelulozy }(\mathrm{CMC})-\text { w formie membrany (M) lub } \\
\text { wysuszonych arkuszy (A) }\end{array}$ & $\begin{array}{l}\text { BC 65-M CMC } \\
\text { BC 65-A CMC }\end{array}$ \\
\hline $\begin{array}{l}\text { Celuloza bakteryjna } 65 \mathrm{~g} / \mathrm{m}^{2} \text { hodowana w obecności } \\
\text { karboksymetylocelulozy (CMC) } \\
\text { arkuszy (A) próbka kontrolna }\end{array}$ & ВC 65-A CMC K \\
\hline $\begin{array}{l}\text { Celuloza bakteryjna } 65 \mathrm{~g} / \mathrm{m}^{2} \text { hodowana w obecności } \\
\text { karboksymetylocelulozy (CMC) - arkusz suszony w prasie } \\
\text { hydraulicznej pod zwieksszonym obciażeniem } 4.5 \mathrm{~T}\end{array}$ & BC 65-A CMC N \\
\hline $\begin{array}{l}\text { Celuloza bakteryjna } 65 \mathrm{~g} / \mathrm{m}^{2} \text { hodowana w obecności } \\
\text { karboksymetylocelulozy (CMC) suszona w formie arkusza } \\
\text { wysuszonego w liofilizatorze }\end{array}$ & $\begin{array}{l}\text { BC 65-A CMC liof } \\
/ \mathrm{L}\end{array}$ \\
\hline $\begin{array}{l}\text { Celuloza bakteryjna } \mathrm{z} \text { dodatkiem węglanu wapnia }\left(\mathrm{CaCO}_{3}\right) \\
\text { w formie membrany (M) lub wysuszonych arkuszy }(\mathrm{A})\end{array}$ & $\begin{array}{l}\text { BC W-A M } \\
\text { BC W-A }\end{array}$ \\
\hline $\begin{array}{l}\text { Celuloza bakteryjna } \mathrm{z} \text { dodatkiem węglanu wapnia próbka } \\
\text { kontrolna }\end{array}$ & BC W-A K \\
\hline $\begin{array}{l}\text { Celuloza bakteryjna } \mathrm{z} \text { dodatkiem węglanu wapnia suszona } \\
\text { w prasie hydraulicznej pod zwiększonym obciążeniem } 4.5 \mathrm{~T}\end{array}$ & BC W-A N \\
\hline
\end{tabular}




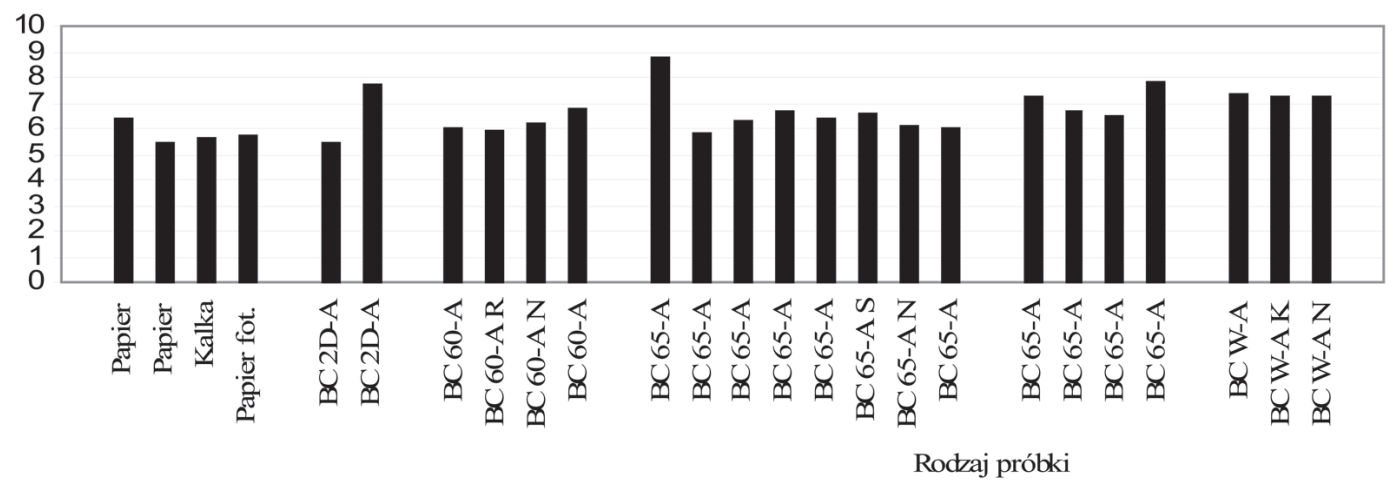

Wykres 1. pH arkuszy wytworzonych z celulozy bakteryjnej w porównaniu do wytworów papierniczych

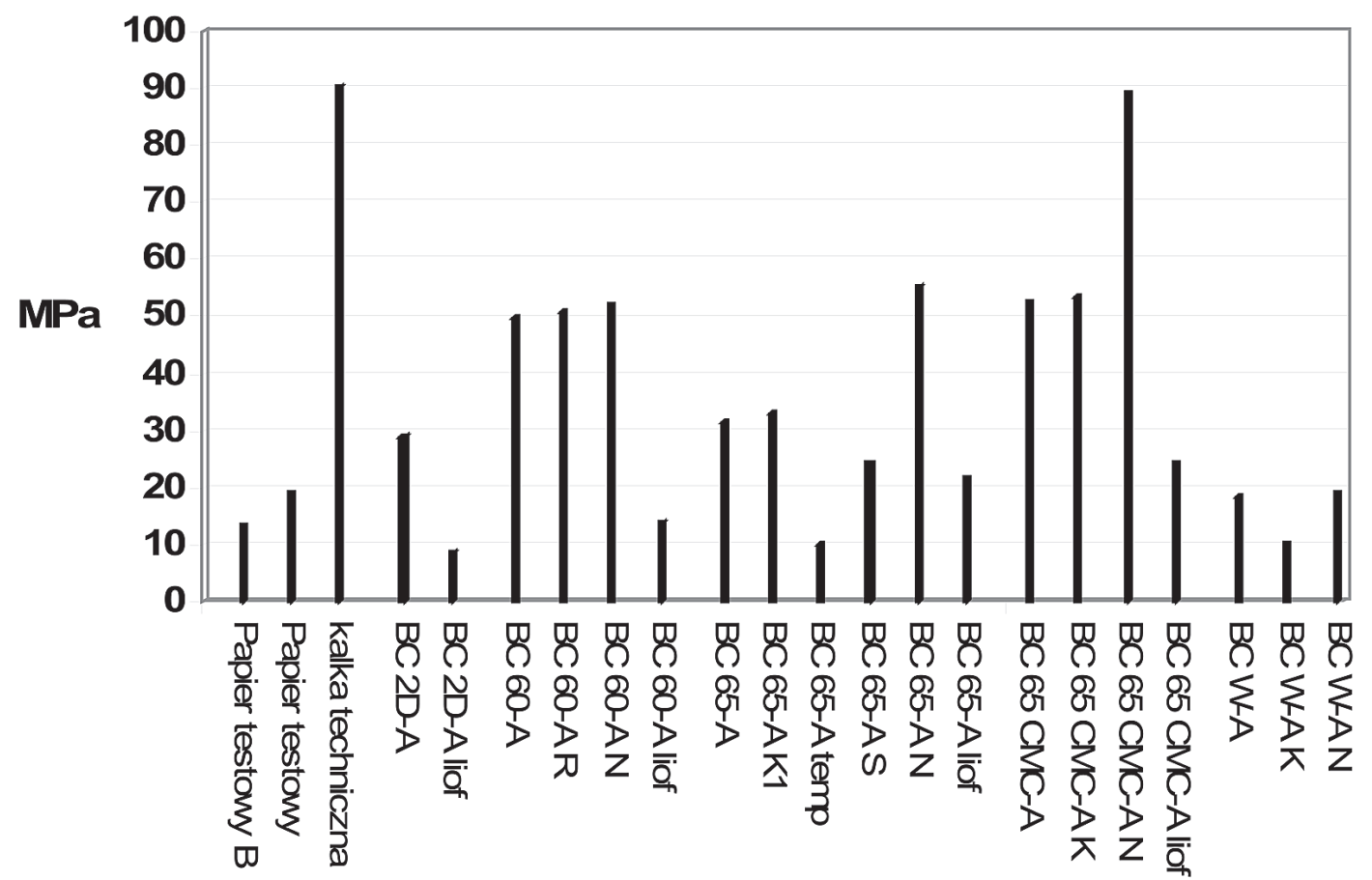

Wykres 2. Odporność na zerwanie arkuszy BC [MPa] ( kierunek wzdłużny) 


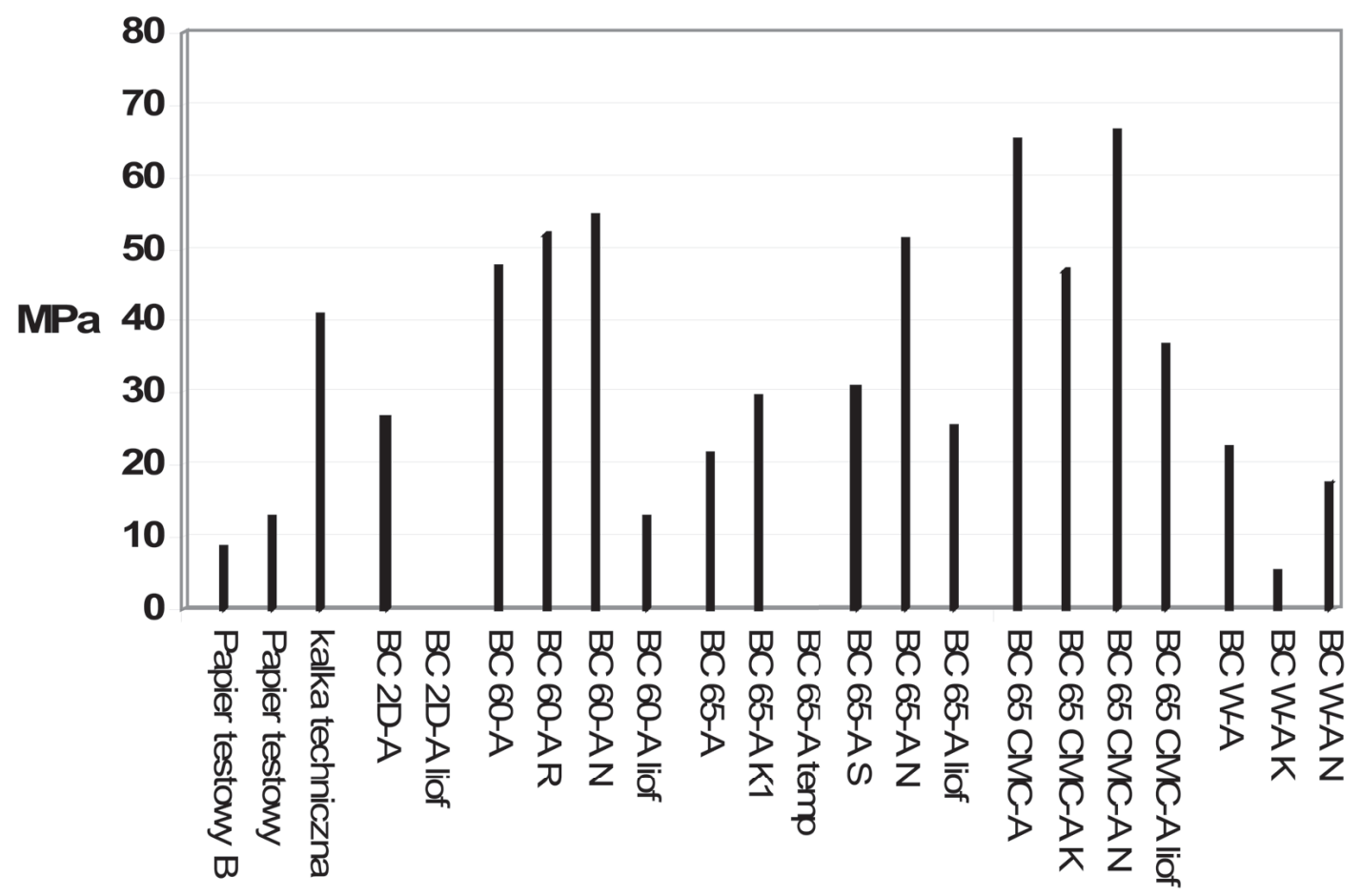

Wykres 3. Odporność na zerwanie arkuszy BC [MPa (kierunek poprzeczny)]

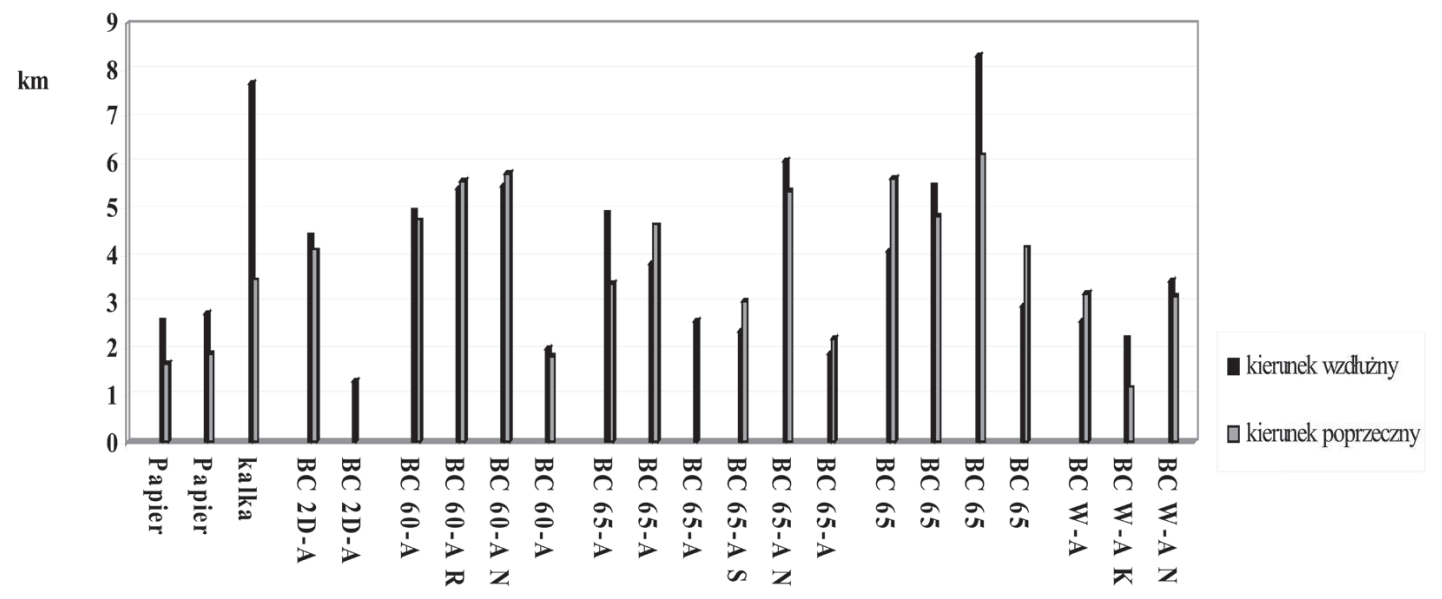

Wykres 4. Samozerwalność arkuszy celulozy bakteryjnej S [km] 


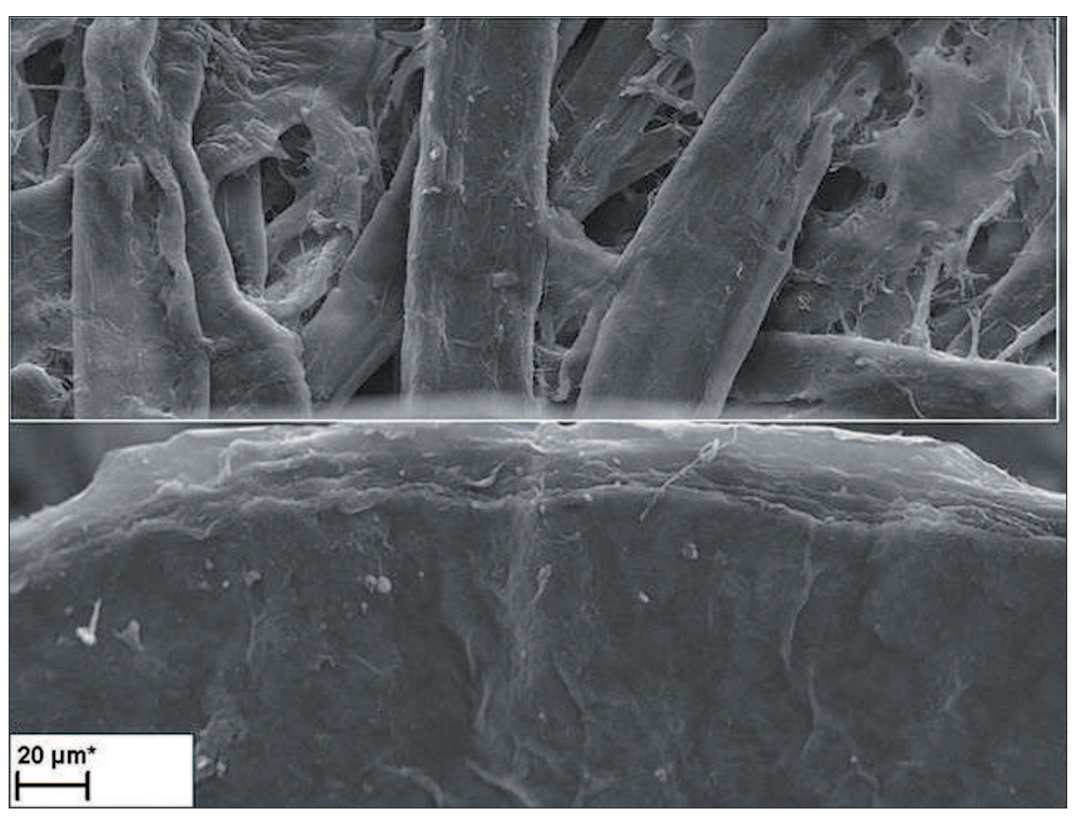

Fot. 9. Błona z hydrożelu celulozy bakteryjnej II-dobowej pomiędzy arkuszem z celulozy bakteryjnej i papierem testowym (SEM pow. 1000×, fot. Grzegorz Trykowski, Pracownia Analiz Instrumentalnych, Wydział Chemii, UMK)

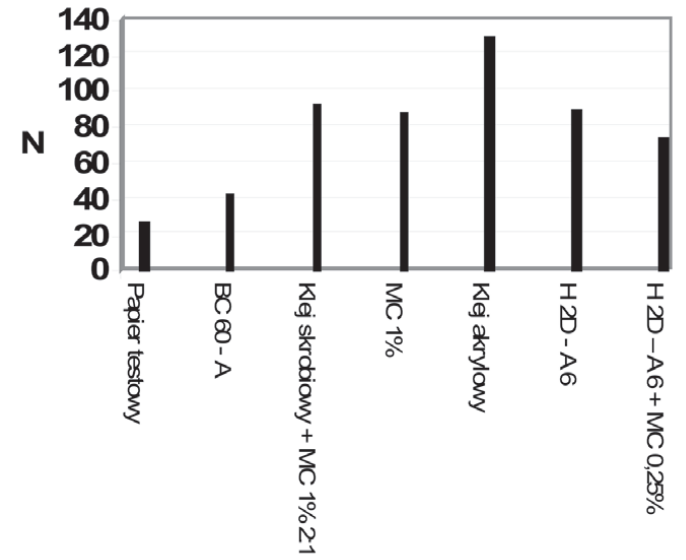

Wykres 5. Siła zrywająca $[\mathrm{N}]$ arkuszy celulozy bakteryjnej zdublowanych na papier testowy za pomoca klejów i hydrożeli z celulozy bakteryjnej 


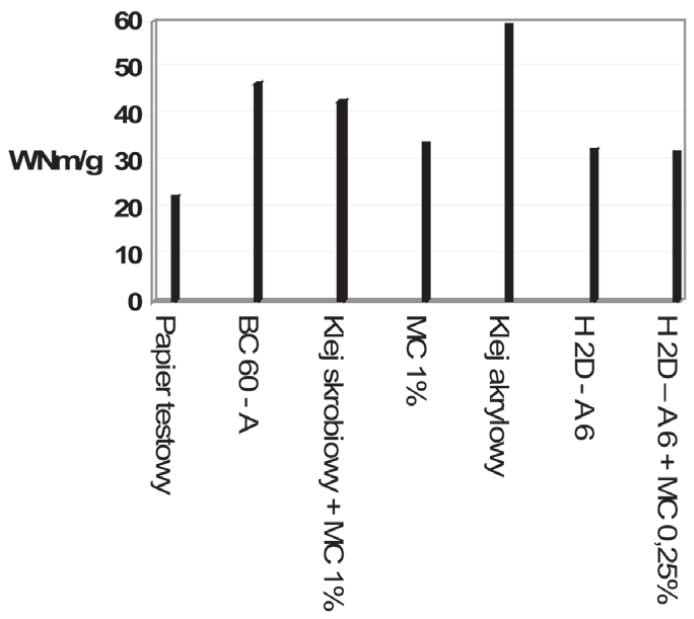

Wykres 6. Wskaźnik rozciagania W [Mn/g] arkuszy celulozy bakteryjnej zdublowanych na papier testowy za pomoca klejów i hydrożeli z celulozy bakteryjnej

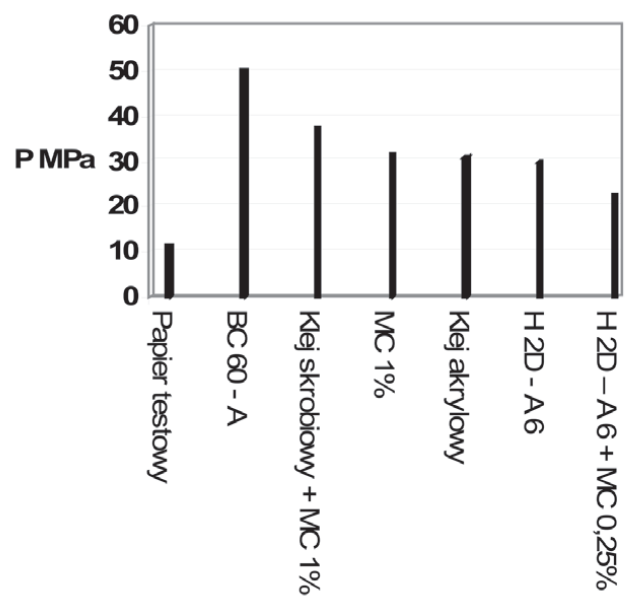

Wykres 7. Odporność na zerwanie P $[\mathrm{MPa}]$ arkuszy celulozy bakteryjnej zdublowanych na papier testowy za pomocą klejów i hydrożeli z celulozy bakteryjnej 
Tab. 3. Rodzaje płynnych mas użytych do uzupełniania ubytków

\begin{tabular}{|c|c|c|}
\hline Lp. & Material uzupeliniany & Masa uzupelmiająca \\
\hline 1. & $\begin{array}{l}\text { Papier recznie czerpany; } \\
\text { Papier maszynowy }\end{array}$ & $\begin{array}{l}\text { Masa bawelniana; } \\
\text { Wökna bawelniane + } \mathrm{BC}(1: 3) \text {; } \\
\text { Wökna bawelniane }+\mathrm{BC}(1: 1) \text {; } \\
\text { Wökna bawelniane + } \mathrm{BC}(3: 1) \text {; } \\
\text { Zawiesina bakteryjnej celulozy; }\end{array}$ \\
\hline 2. & Kallka technniczna & Zawiesina bakteryjnej celulozy: \\
\hline 3. & Plótno lniane: & $\begin{array}{l}\text { Masa lniana; } \\
\text { Wlökna lniane + } \mathrm{BC}(1 \cdot 3) \text {; } \\
\text { Wlókna lniane + } \mathrm{BC}(1: 1) \text {; } \\
\text { Wlökna lniane+ } \mathrm{BC}(3: 1) \text {; } \\
\text { Zawiesina bakteryinej celulozy; }\end{array}$ \\
\hline 4. & $\begin{array}{l}\text { Tkanina jedwabna o splocie plociennym; } \\
\text { Tkanina jedwabna o splocie atlasowym }\end{array}$ & $\begin{array}{l}\text { Masa jedwabna: } \\
\text { Wlókna jedwabne + BC }(1: 3) \text {; } \\
\text { Wlóknal jedwabne + BC }(1: 1) \text {; } \\
\text { Wlókna jedwabne + BC }(9: 1) \text {; } \\
\text { Zawiesina bakteryjnej celulozy; }\end{array}$ \\
\hline 5. & Pergamin 1 & $\begin{array}{l}\text { Wlókna pergaminowe } 1+\mathrm{BC}(1: 3) \text {; } \\
\text { Wlókna pergaminowe } 1+\mathrm{BC}(1: 1) \text {; } \\
\text { Wlókna pergaminowe } 1+\mathrm{BC}(3: 1) ; \\
\text { Zawiesina bakteryjnej celulozy; }\end{array}$ \\
\hline 6. & Pergamin 2 & $\begin{array}{l}\text { Wlókna pergaminowe } 2+\mathrm{BC}(1: 3) \text {; } \\
\text { Wlókna pergaminowe } 2+\mathrm{BC}(1: 1) \text {; } \\
\text { Wlókna pergaminowe } 2+\mathrm{BC}(3: 1) \text {; } \\
\text { Zawiesina bakteryjnej celulozy; }\end{array}$ \\
\hline 7. & Skóra 1 & $\begin{array}{l}\text { Wlókna skórzane } 1+\mathrm{BC}(1: 3) \\
\text { Wlókna skónzane } 1+\mathrm{BC}(1: 1) \\
\text { Wlókna skórzane } 1+\mathrm{BC}(3: 1) \\
\text { Zawiesina bakteryjnej celulozy; }\end{array}$ \\
\hline 8. & Skóra 2 & $\begin{array}{l}\text { Wlókna skórzane } 2+\mathrm{BC}(1: 3) \\
\text { Wlólnna skórzane } 2+\mathrm{BC}(1: 1) \\
\text { Wlökna skórzane } 2+\mathrm{BC}(3: 1) \\
\text { Zawiesina baktervinej celulozy; }\end{array}$ \\
\hline
\end{tabular}



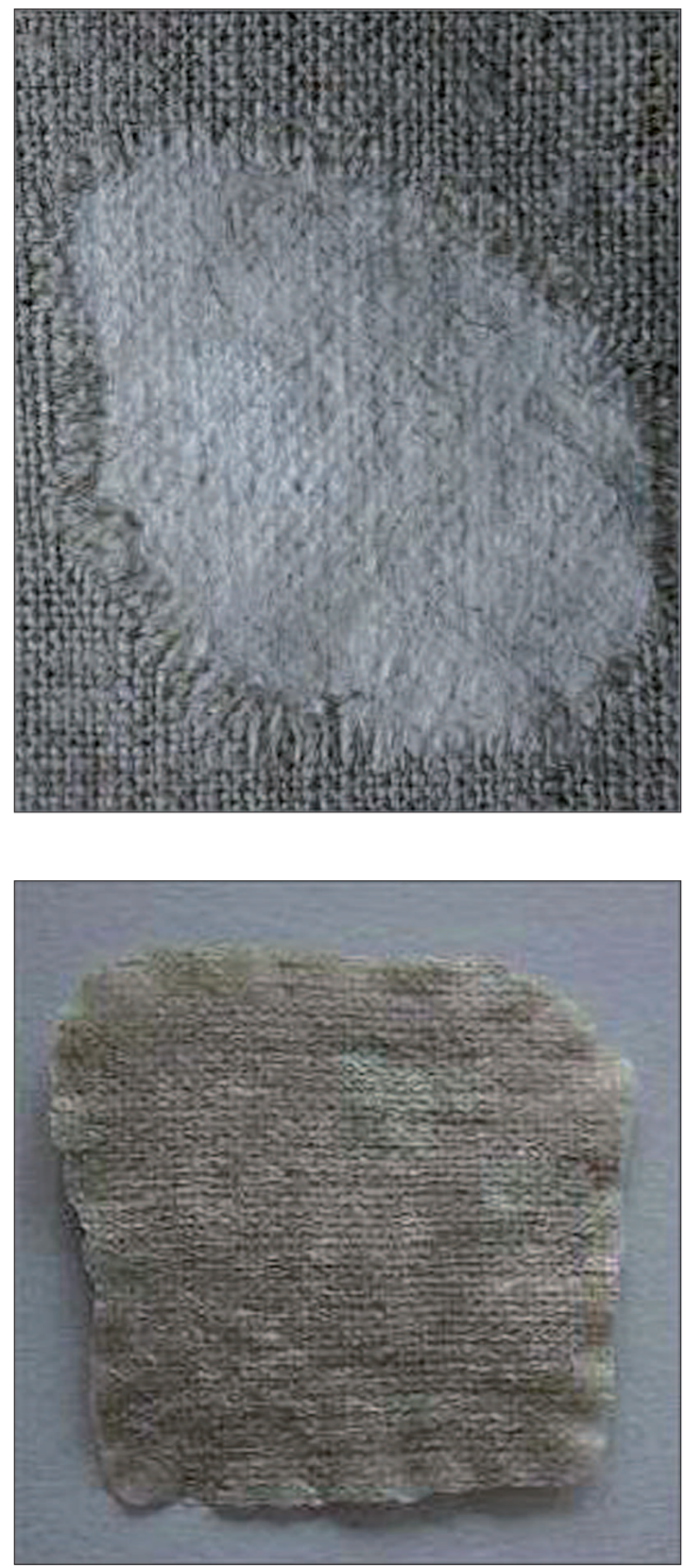

Fot. 10 a, b. a - uzupełnienie płótna lnianego masa włókna lniane + BC 3: 1, b - zawiesina celulozy bakteryjnej z nadana faktura płótna lnianego 